\title{
On the Symbolism of Color in Dubliners
}

\author{
ZHANG Tian-yi, JIA Xiao-yun \\ University of Shanghai for Science and Technology, Shanghai, China
}

\begin{abstract}
This article researches the function of color symbols on expressing the theme by analyzing the original text. By doing such researches, the relationship of symbol with deepening the theme can be clearly revealed.

Keywords: Dubliners, Jam Joyce, color symbolism
\end{abstract}

\section{Introduction}

In creating Dubliners, Jam Joyce chooses the capital of Ireland as its background and vividly describes various kinds of lifestyle and mentation in order to uncover the numbness of people and paralysis of the whole society. This short story made up of 15 stories displays the fierce conflict between people and the whole society and the bitter feeling after failure (Qiang, 2004).

\section{Color Symbols}

As one of the important rhetoric method, color symbol has strong metaphorical meaning. It is often used to describe abstract things and people's character, living features and mood, which makes the expression vividly (Li, 2007). Different colors brings various kinds of feelings for human beings, this is to say, different colors represent different moods, so we can judge moods, beliefs, nature of people through colors. In this novel, the author uses a lot of colors to vividly express the numbness of people in current society as a result of the brutal war. It's very hard for people to gain confidence after war. So most people remain stagnate to escape the pain brought by the sufferings. This article analyses how the color symbolism makes the theme of Dubliners more clearly known by the readers.

\section{White-Last Purity of Human Nature}

White represents elegance and pureness and is the symbol of the God, the angle, happiness and the virtue. In the Bible, the angle has white wings and silvery white halo over the head. When white expresses the feeling of human beings, it has the meaning of bright, cold, and happiness. It shows the purity and honesty in the human nature (Zhou, 2006). In this novel, the author uses white to express the last purity in people's heart that is not destroyed by that paralysis society. The short passage An Encounter describes the story of two school boys running away from home and coming back at last. By the river, when they saw the big white sailing-vessel, one of the boys - Mahony said "it would be right skit to run away to a sea on one of those big ships" (Joyce, 2011, p. 13). Besides, the narrator also says when he looks at the high masts and feels that school and home seem to recede from them. Here, the big white ship is the carrier of their feelings in their heart that is

ZHANG Tian-yi, Master of Arts, College of Foreign Languages, University of Shanghai for Science and Technology, Shanghai, China.

JIA Xiao-yun, associate professor, College of Foreign Languages, University of Shanghai for Science and Technology, Shanghai, China. 
seeking for the freedom, because something across from the sea is novel and strange, which makes them feel exciting. Therefore, "white" here represents their deep desires to escape from the current situation. In the short passage of The Boarding House, the description of the leading character is that "her hopes and visions of were so intricate that she no longer saw the white pillows on which her gaze was fixed or remembered that her was waiting for anything” (Joyce, 2001, p. 56). And later, when her mother tells her that Mr. Doran wants to speak to her, she knows what she has been waiting for. Through these details, it can be found out that the white pillows are the symbolism of thousands of thoughts and minds of the leading character. At the beginning, she cannot find out what she wants most, and when Mr. Doran appears, she finds what her desires best. In the short passage of The Dead, Gretta and her husband Gabriel do not have a very good relationship with each other. But, in the past, they lived very happy. Gabriel often think of the happy time ever had because it can make him forget the unhappy and impassionate life provisionally. And it is the only console for the unhappy marriage. When the cab drove across O'Connell Bridge, he is in a happy mood when Gabriel remembers he was again in a cab with his wife, hallooing to their honeymoon. "As the cab drove across O'Connell Bridge, Miss O’Callaghan said: 'they say you never across O'Connell Bridge without seeing a white horse'. 'I see a white man this time', said Gabriel”. "Gabriel pointed to the statue, on which lay patches of snow. Then he nodded familiarly to it and waved his hand" (p. 192). It is easily can be found that at this moment, he is very satisfied and happy. The dialogue between Miss O’Callaghan and Gabriel mentioned two things "white horse" and "white man". Although readers cannot tell what the horse and sculpture represent, the two things have the same features - they are both white things. The white makes the bridge a special and famous place and the white sculpture regarded as a man. The narrator wants to express purity human nature by using white color to describe pure things. Image that when you see a big white horse without stains and a large sculpture covered by white snow, you must feel peaceful and wonderful. It's just like Gabriel's feeling of remembering the past happy time. He loves his wife very much while the current situation is not so satisfactory. So the color white represents love in his heart under the strong appearance. So, through the three examples, the story of the first part is about chasing freedom of children and the second and third part are about the love of adults; it can be said in this novel, the author wants to use "white" to show that the last purity still exists in people's heart though this society has gradually fallen into paralysis.

\section{Grey-The Current State of Paralysis}

Gray is a color, mixed with white and black. It's the cold color of concrete, of industrial waste, of devouring living beings and represents gloom, weakness, dirtiness, depression, and intrigue (Cheng, 2016). In the novel, the author wants to express two phenomena: the numbness of people and the paralysis of the whole society by using the symbolism of "grey". In the first part, the narrator mentioned the "grey face" three times, which aims to put emphasis on the poor condition of people in this country. "In the dark of my room I imagined that I saw again the heavy grey face of the paralytic. But the grey face still followed me. His face was very truculent, grey and massive” (Joyce, 2011, p. 6). The reason why the author chooses the priest as the first main character in the novel is that his position is very holy. He has the least probability to commit crime or becomes "paralyzed”. However, he does. And at others' places, the author mentioned "grey hair" at several times. In The Dead, when describing Aunt Julia, the author mentions "Her hair, drawn low over the tops of her ears, was grey; and grey also, with darker shadows, was her large flaccid face, and author thinks that she does not know where she is or where she is going” (Joyce, 2011, p. 160). Through this description on Aunt Julia, we can easily find 
that her life is stagnant. When Gabriel tells a joke, Aunt Kate and Aunt Julia laugh happily. But, the smile soon leaves from the face of the Aunt because she does not know very well about the meaning of the word "galoshes". From these details, we can know that the life of Aunt Julia is so closed that she cannot receive new information. To some extent, Aunt Julia is very old and has no chance and strength to chase new life instead of current life. So it is obvious that she is numb in her life.

The atmosphere of society is so depressed that people who live in it try to escape. But, not every escape succeeds. Those people who failed become numb and lose hope for life. So everything described with the color "grey" is aimed to focus on the theme of paralysis for people in the society or the society itself.

\section{Blue-Another World of Human Fantasy}

The color "blue" is light, cold, and cool in texture from the perspective of color science, which expands one's field of vision to blue sea and blue sky. When "blue" is combined with dark, it has the meaning of fear and destruction. While combined with light, it symbolizes hope and freedom. It is often used in literary works to show another world of human fantasy (Li, 2006). In the passage of After The Race, the blue cars belong to the French and "each blue car, therefore, received a double measure of welcome as it topped the crest of the hill" (Joyce, 2011, p. 31). In the passage of "Two Gallants", a young woman is in blue dress and a white sailor hat. As soon as she appears, the two main characters become excited.

"Blue" is also used to describe a young woman: "Her blue serge skirt was held at the waist by a belt of black leather" (Joyce, 2011, p. 44). In the passage of A Mother, "few young men, wearing bright blue badges in their coats, stood idle in the vestibule" (Joyce, 2011, p. 121). In the last passage of this novel The Dead, "her blue felt hat would show off the bronze of her hair against the darkness" (Joyce, 2011, p. 206). Although these blue things are all very little, such as cars, dress of woman, badges..., we can figure out that these things have same features - popular and attractive. As we all know, different from fortitude and firm of male, female is soft and beautiful, so throughout the novel, the author uses "blue" to describe women. Based on such information, we can speculate that "blue" is used to express a society full of active things and beautiful people that is very different from the current society.

\section{Conclusion}

Based on the analysis about different colors, we can find that the color symbols play a significant role in expressing the theme. Color "White" is used to express the last purity of chasing good things in their heart that is not destroyed by that society. For children, freedom is precious because they have not it. However, influenced by the society, the adult have many things, such as money, social position, good reputation, and so on except true intention of human nature. Just like the color "white", which is never to be added with other colors, the true happiness deep inside can never be destroyed by cruel trauma, maybe it is not easily to find. The atmosphere of the whole society is grey and depressed, because people around have grey eyes, grey faces, and so on. They are not satisfied with their life, their friends, their lovers, but they still have no courage to change their life or to leave. However, many blue things such as the cars, the clothes of the woman, which shows people may still pursue beauty in their heart. The color symbols provide an easy way for readers to understand the situation of the society and people living in this society. Moreover, the expressionism of color symbols offers a vivid picture of the society at that time. 


\section{References}

Cheng, J. F. (2016). Color symbol in the movie The Great Gatsby. Movie Literature, 138-140.

Joyces, J. (2011). Dubliners. Beijing: Foreign Language Teaching and Research Press.

Li, J. Y. (2006). Color performance and implication of the movie "Blue”. Movie Commentary, 29, 34.

Li, J. L. (2007). A comparative study of the symbolic meanings of color words in English and Chinese languages. Journal of Jishou University, Social Science Edition, 28(4), 173-175.

Qiang, Y. X. (2004). Paralysis that is hard to escape-Comment on the theme of Joyce's Dubliners. Journal of Tangshan Normal University, 26(3), 27-29.

Zhou, X. M. (2006). The meaning and symbolic meaning of some color words in English. Teaching and Management, 91-92. 